\title{
Giant left parietal lobe arachnoid cyst presenting as early-onset dementia
}

\author{
Rishi Raj, Ajay Venkatanarayan, Ahmad Sharayah, Douglas Ross
}

Department of Internal Medicine, Monmouth Medical Center, Long Branch, New Jersey, USA

\section{Correspondence to} Dr Rishi Raj, rishiraj91215@gmail.com

Accepted 27 April 2018

\section{DESCRIPTION}

A 56-year-old woman with no significant medical history was brought for evaluation of difficulty with speaking for 1 month. Family reported patient having short-term and long-term memory impairment and gradual cognitive decline over a course of 2 years. Her mother had Alzheimer's dementia in her 60s and the patient attributed her symptoms to Alzheimer's and did not seek medical attention until she developed word finding difficulty. On neurological examination, she had expressive aphasia and scored 20 on Mini-mental state examination (MMSE). Laboratory work-up showed normal haemogram, metabolic panel, thyroid function tests, vitamin B12 and folic acid levels and a negative rapid plasma reagin (RPR) test. MRI showed a giant left cerebral hemisphere arachnoid cyst with $11 \mathrm{~mm}$ midline shift to the right (figure 1). She underwent stereotactic craniotomy with microsurgical excision of the arachnoid cyst. Postoperative hospital course was complicated by generalised tonic-clonic seizure, controlled with antiepileptic medications. On 6-week follow-up, patient had resolution of expressive aphasia and mild improvement in her cognitive function.

Arachnoid cysts are cerebrospinal fluid-filled sacs located between brain or spinal cord and arachnoid membrane. ${ }^{1}$ Primary arachnoid cysts are more common and congenital in origin whereas secondary arachnoid cyst can develop as a complication of brain surgery, head injury, tumour or meningitis. ${ }^{1}$ These comprises about $1 \%$ of all intracranial mass with approximately 50\%-60\% occurring in the middle cranial fossa. ${ }^{12}$ Males are four times more likely to have arachnoid cysts than females. ${ }^{2}$ Elderly patients with arachnoid cyst usually present with headache, nausea and vomiting, vertigo, gait disturbance and dementia, mimicking chronic subdural haematoma and normal pressure hydrocephalus. ${ }^{23}$
D Check for updates

To cite: Raj $R$, Venkatanarayan $A$,

Sharayah A, et al. BMJ Case Rep Published Online First: [please include Day Month Year]. doi:10.1136/bcr-2018 224837

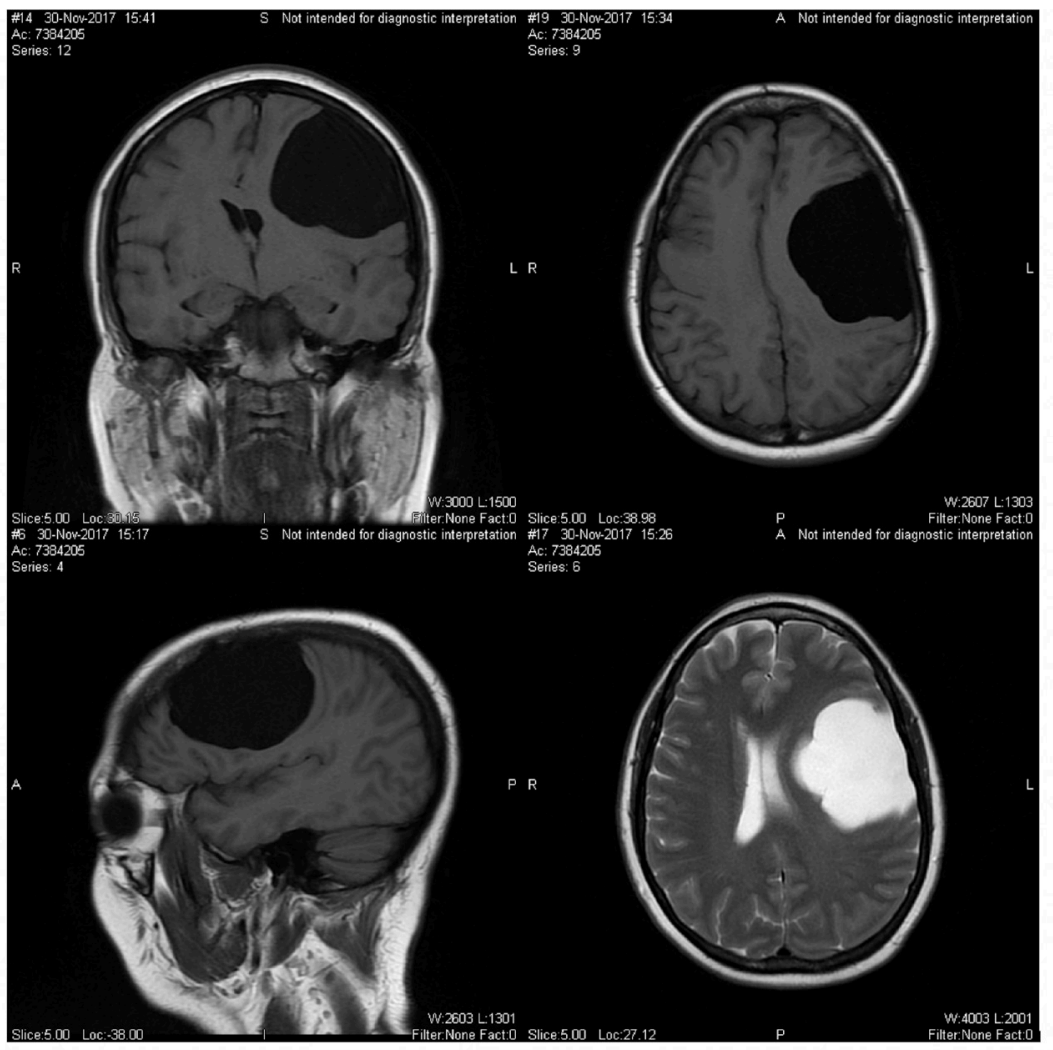

Figure 1 T1-weighted coronal (left upper), sagittal (right upper) and axial (left lower) images on MRI brain without contrast showing left parietal lobe arachnoid cyst measuring $6.7 \mathrm{~cm} \times 5.3 \mathrm{~cm}$ with $11 \mathrm{~mm}$ midline shift to the right. T2- weighted sagittal (right lower) images of the brain showing isointensity with cerebrospinal fluid. There is the homogeneity of the lesion, lack of perceptible wall and lack of internal complexity which are suggestive of an arachnoid cyst. 


\section{Learning points}

- Thorough work-up is of utmost importance to rule out reversible causes of dementia, even in cases with very strong family history of Alzheimer's dementia.

- Arachnoid cysts, although more common in younger patients, should always be considered as a differential diagnosis for a patient being evaluated for neurological symptoms.

- Removal of arachnoid cyst with neurosurgical interventions can significantly improve neurological symptoms.

MRI is the diagnostic study of choice in the detection of intracranial arachnoid cysts. Neurosurgical procedures like craniotomy with cyst wall excision, stereotactic cyst aspiration, shunting of cystic fluid to the peritoneal cavity and endoscopic fenestration of cysts to the subarachnoid space or the ventricles can be used to decompress the cyst. ${ }^{2}$
Contributors All authors were directly involved in the care of the patient and contributing to this article.

Funding The authors have not declared a specific grant for this research from any funding agency in the public, commercial or not-for-profit sectors.

Competing interests None declared.

Patient consent Obtained.

Provenance and peer review Not commissioned; externally peer reviewed.

(C) BMJ Publishing Group Ltd (unless otherwise stated in the text of the article) 2018. All rights reserved. No commercial use is permitted unless otherwise expressly granted.

\section{REFERENCES}

1 Rafiq MK. Arachnoid cyst masquerading as Alzheimer's disease. BMJ Case Rep 2009:2009:bcr1120081284.

2 Kotil K, Balci N, Bilge T. Intracranial symptomatic giant arachnoid cyst of the interhemispheric fissure presenting with frontal lobe syndrome. Turk Neurosurg 2007;17:147-51

3 Rabiei K, Jaraj D, Marlow T, et al. Prevalence and symptoms of intracranial arachnoid cysts: a population-based study. J Neurol 2016;263:689-94.

Copyright 2018 BMJ Publishing Group. All rights reserved. For permission to reuse any of this content visit http://group.bmj.com/group/rights-licensing/permissions.

BMJ Case Report Fellows may re-use this article for personal use and teaching without any further permission.

Become a Fellow of BMJ Case Reports today and you can:

- Submit as many cases as you like

- Enjoy fast sympathetic peer review and rapid publication of accepted articles

- Access all the published articles

- Re-use any of the published material for personal use and teaching without further permission

For information on Institutional Fellowships contact consortiasales@bmjgroup.com

Visit casereports.bmj.com for more articles like this and to become a Fellow 